\title{
Role of functional trait variability in the response of individual phytoplankton species to changing environmental conditions in a coastal upwelling zone
}

\author{
Jaime Otero $^{1, *}$, Antonio Bode ${ }^{2}$, Xosé Antón Álvarez-Salgado ${ }^{1}$, Manuel Varela ${ }^{2}$ \\ ${ }^{1}$ Instituto de Investigaciones Marinas (IIM-CSIC), Eduardo Cabello 6, 36208 Vigo, Spain \\ ${ }^{2}$ Centro Oceanográfico de A Coruña, Instituto Español de Oceanografía, Apdo. 130, 15080 A Coruña, Spain
}

\begin{abstract}
The dynamics of individual phytoplankton species are often more variable than predicted for their functional groups. This observation is poorly understood in highly perturbed coastal systems. Trends in the abundance of 54 phytoplankton species spanning a volumetric size range from $\sim 10^{2}$ to $\sim 10^{5} \mu \mathrm{m}^{3}$ in shelf waters of the NW Iberian upwelling system since the late 1980s were modelled as a function of environmental variables. Functional traits were assessed for their ability to explain the across-species changes in occurrence and abundance due to the environmental drivers. Species-specific responses to the environment were heterogeneous, precluding any generalisation by taxonomic groups, although these responses were partially related to cell size. Smaller species showed a high probability of occurrence and higher abundance under high nitrate concentration in the euphotic layer, pointing to a major role of the upwelling of Eastern North Atlantic Central Water but also to inputs of nutrients mineralised over the shelf. However, cell size explained only a small amount of the variability in the individual species' responses to the environment. Growth rate and maximum rate of nitrogen uptake normalised to cell size provided additional explanation for the individual species' responses to the environmental drivers. Fast-growing species, though less efficient in taking up upwelled nutrients, thrived in favourable upwelling conditions. These results support the dominance of species of intermediate size during blooms in this upwelling region, and suggest that variability in functional traits among species rather than cell size alone affects the response of phytoplankton to environmental changes in upwelling ecosystems.
\end{abstract}

KEY WORDS: Phytoplankton $\cdot$ Cell size $\cdot$ Functional traits $\cdot$ Sea surface temperature $\cdot$ Nutrients Upwelling $\cdot$ NW Iberian margin

\section{INTRODUCTION}

Marine phytoplankton are responsible for roughly $50 \mathrm{Pg} \mathrm{C}_{\mathrm{yr}}{ }^{-1}$ of global net primary production (Chavez et al. 2011). This primary production supports all marine food webs (e.g. Croll et al. 2005), plays an essential role in global biogeochemical cycles and climate (Falkowski et al. 2008) and constrains the spatio-temporal variability of global fisheries catches (Chassot et al. 2010). Photosynthetic net primary production depends on nutrient supply processes largely

${ }^{*}$ Corresponding author: jotero@iim.csic.es controlled by environmental variability and climatedriven fluctuations that regulate the nutrient fluxes in the water column (Chavez et al. 2011). Nutrients are abundant in eutrophic coastal zones and lead to transient blooms often dominated by diatoms (Carstensen et al. 2015). The resultant biomass is rapidly transferred up the food web to grazers and pelagic fishes, particularly in Eastern Boundary Upwelling Ecosystems (EBUEs), where wind-driven upwelling supplies nutrients supporting around $5 \%$ of global marine primary production (Carr 2001) and

(C) The authors 2018. Open Access under Creative Commons by Attribution Licence. Use, distribution and reproduction are unrestricted. Authors and original publication must be credited. 
$20 \%$ of worldwide fisheries (Chavez \& Messié 2009). Alterations in the physical conditions and climatedriven changes in EBUEs might have important implications for biogeochemical cycles, phytoplankton and zooplankton composition and abundance, phenological responses or overall ecosystem productivity (Rykaczewski \& Dunne 2010, Bakun et al. 2015). Thus, understanding the mechanisms that determine the changes in phytoplankton abundance and biomass in coastal areas, and upwelling systems in particular, is timely.

Documenting changes in phytoplankton abundance and composition is common in the literature, though mostly focused on studying long-term changes in taxonomic groups (e.g. Hernández-Fariñas et al. 2014) or on investigating different assemblages in relation to seasonal succession (e.g. Casas et al. 1999). Far fewer studies have been devoted to analysing changes in the response of individual phytoplankton taxa to environmental perturbations, which can differ even within the same taxonomic group (e.g. Mutshinda et al. 2013). It is, indeed, this interspecific variation in response to environmental conditions that is the mechanism that determines the community assembly (Edwards et al. 2013, Marañón 2015, Sommer et al. 2017). In particular, major phytoplankton groups often differ in average functional trait values, implying a plethora of diverse performances and fitness under contrasting conditions (see Barton et al. 2013a and references therein). For example, nutrient utilization traits (Edwards et al. 2012) and light-use traits (Edwards et al. 2015a) reveal different ecological strategies among major phytoplankton taxa and help to explain community structure and responses to seasonal environmental fluctuations (Edwards et al. 2013). Many of these physiological rates and tradeoffs across traits and other ecological properties are related to, and constrained by, cell size (Edwards et al. 2011, Marañón 2015). Thus, cell size is usually considered as a metaor master-trait (Litchman \& Klausmeier 2008, Barton et al. 2013a), playing a key role in determining phytoplankton metabolism and community assembly along environmental gradients (Barton et al. 2013b, Marañón 2015). Partitioning phytoplankton abundance or biomass among species of different cell sizes has provided useful insights on the organization and function of phytoplankton communities, particularly when considering a large range of individual sizes (Cavender-Bares et al. 2001, Cermeño \& Figueiras 2008, Huete-Ortega et al. 2010). However, cell size alone is insufficient for understanding key functional aspects of phytoplankton ecology as the domi- nance structure of blooms (Sommer et al. 2017); thus, other physiological and ecological traits need to be considered (Edwards et al. 2013, Harvey et al. 2015, Klais et al. 2017).

Galicia is at the northern boundary of the Iberia/ Canary EBUE (see Fig. 1). Coastal winds at these latitudes $\left(42\right.$ to $\left.44^{\circ} \mathrm{N}\right)$ are seasonal; northerly winds prevail from March-April to September-October, promoting coastal upwelling, while downwellingfavourable southerly winds predominate the rest of the year. However, more than $70 \%$ of the variability in coastal winds occurs in periods of $<1 \mathrm{mo}$, so that the upwelling season appears as a succession of wind-stress events separated by wind-calm episodes, with a wide variety of frequencies ranging from 3 to 15 d (Álvarez-Salgado et al. 2002). Previous studies in the region have shown that these oceanographic conditions have multiple impacts on the broad variability of primary producers. In the short term, upwelling events and wind-calm episodes affect both phytoplankton community composition and seasonal succession (Casas et al. 1997, 1999) and the size scaling of phytoplankton abundance (Huete-Ortega et al. 2010). In the long term, recent analyses have provided evidence of increases in phytoplankton biomass (Pérez et al. 2010), primary production (Bode et al. 2011) and total cell abundance (Bode et al. 2015a). These patterns were attributed to increases in the stability of the water column and in the remineralization of organic matter near the coast rather than to increases in nutrient fertilization associated with upwelling (Pérez et al. 2010, Doval et al. 2016). However, long-term changes in the composition of the phytoplankton community were less clear, as there were reports of increasing trends in the proportion of dinoflagellates while diatoms decreased (Pérez et al. 2010), but also non-significant variations in the abundance of both diatoms and dinoflagellates (Bode et al. 2009). Furthermore, analyses of the trends in abundance of individual species showed that there was a large variety of responses to environmental and climate variability, even for species belonging to the same taxonomical group (Bode et al. 2015a).

Here, using a large set of phytoplankton composition data collected at a shelf station off A Coruña (NW Iberian upwelling system) over a $22 \mathrm{yr}$ period, we (1) quantified the responses of the abundance of individual species to changes in sea surface temperature, nutrient concentration and upwelling intensity for a set of 54 phytoplankton species, (2) evaluated the role of volumetric cell size in structuring individual responses to the environmental drivers within 
this coastal upwelling system, and (3) assessed the degree to which species-specific responses to the environment were also constrained by their maximum growth rate, optimum temperature for growth and nutrient uptake, all measured from laboratory experiments reported in the literature.

\section{MATERIALS AND METHODS}

\section{Phytoplankton sampling}

Phytoplankton identification and count data were obtained from the time series project RADIALES conducted by the Instituto Español de Oceanografía off A Coruña (NW Spain; Fig. 1), which has been in operation since 1987 (Bode et al. 2009). Specifically, water samples were collected monthly with 51 Niskin bottles or a rosette sampler from $0,5,10,20,30,40$ and $70 \mathrm{~m}$ depths at Stn E2 (43 $25^{\prime} 30^{\prime \prime} \mathrm{N}, 8^{\circ} 26^{\prime} 20^{\prime \prime} \mathrm{W}$, water depth: $80 \mathrm{~m}$; Fig. 1) from January 1989 to December 2010 ( $\mathrm{n}=261$ days sampled). For each depth, samples were collected for the determination of phytoplankton abundance and nutrient and chlorophyll a (chl a) concentration following the methods described in Casas et al. (1997, 1999). Phytoplankton samples of volume 50 to $100 \mathrm{ml}$ were preserved in Lugol's solution and kept in the dark until analysis. Depending on phytoplankton concen-

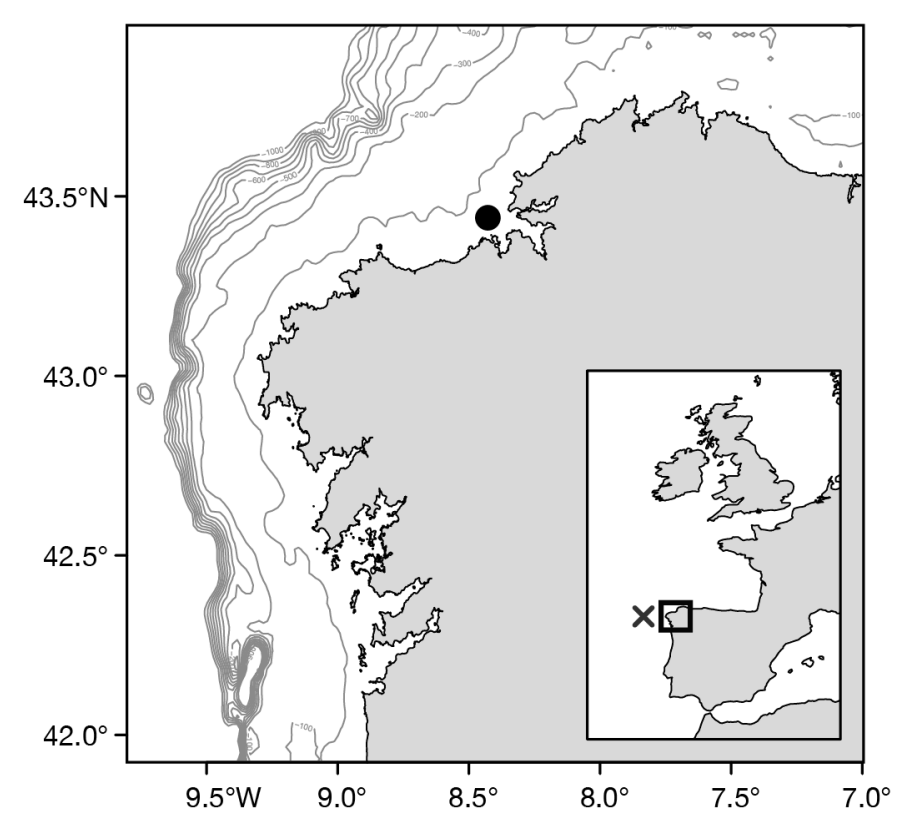

Fig. 1. Sampling site showing Stn E2 (black dot) off A Coruña (NW Spain) and the location of the grid cell at $43^{\circ} \mathrm{N}, 11^{\circ} \mathrm{W}$ (black cross) used to calculate the upwelling index tration, 10 to $25 \mathrm{ml}$ of sample were allowed to settle in an Utermöhl chamber for up to $24 \mathrm{~h}$. Samples were always counted by the same person (co-author M.V.) following the technique described by Utermöhl (Lund et al. 1958), using a Nikon Diaphot TMD microscope until May 1997 and a Nikon Eclipse TE300 microscope until the end of the time series. A magnification of $100 \times$ was used for large forms, $250 \times$ for intermediate forms and $400 \times$ and $1000 \times$ for microflagellates. The entire slide was examined at $100 \times$ to account for large species while only transects or smaller areas were examined at higher magnification. At least 250 cells were counted for each sample. Whenever possible, organisms were classified to the species or genus level. Species nomenclature followed the World Register of Marine Species (www.marine species.org). For the purposes of the present work, we used the most abundant and recurrent species resulting in a set of 54 taxa summarised in Table S1 \& Fig. S1 in the Supplement at www.int-res.com/articles/ suppl/m596p033_supp.pdf. The original dataset is available from the PANGEA repository at http://doi. pangaea.de/10.1594/PANGAEA.855901 (Bode et al. 2015b).

\section{Biogeochemical sampling and analysis}

At the same time and with the same periodicity, vertical profiles of temperature and salinity were measured with a CTD probe (Seabird SBE-25). The salinity of the CTD was checked against the salinity of bottom water samples measured with an induction salinometer (Autosal 8400A), calibrated with standard seawater (Casas et al. 1997). Salinity was calculated using the practical salinity scale (UNESCO 1986). Dissolved inorganic nitrate concentration $\left(\mathrm{NO}_{3}{ }^{-}\right.$; in $\left.\mathrm{mmol} \mathrm{m}{ }^{-3}\right)$ was determined with an autoanalyser (Technicon AA-II) according to the standard procedures of Grasshoff et al. (1983). Chl a concentration (in $\mathrm{mg} \mathrm{m}^{-3}$ ) was measured by fluorometric analysis of acetone extracts of phytoplankton collected on $0.8 \mu \mathrm{m}$ pore size membrane filters (until 1992) or glass-fibre GF/F type filters (from 1993 onwards). Specific calibrations were performed to ensure the continuity of the chlorophyll series when changing from the filter fluorometer method (Parsons et al. 1984) to the spectrofluorometric technique (Neveux \& Panouse 1987) after 2001. In this study, we used the water-column integrated chl $a$ and the nitrate concentration integrated in the upper $40 \mathrm{~m}$ (average depth of the euphotic zone as determined with the irradiance sensor of the CTD). 


\section{Physical forcing}

Daily upwelling index (UI; in $\mathrm{m}^{3} \mathrm{~s}^{-1} \mathrm{~km}^{-1}$ ) data, a rough estimate of the volume of water upwelled per $\mathrm{km}$ of coast for the period 1989 to 2010, were downloaded from www.indicedeafloramiento.ieo.es/index UI_en.html. UI was estimated from geostrophic winds calculated from the surface atmospheric pressure fields analysed every $6 \mathrm{~h}$ by the Fleet Numerical Meteorological and Oceanography Center (www.usno. navy.mil/FNMOC/) in a $2^{\circ} \times 2^{\circ}$ grid centred at $43^{\circ} \mathrm{N}$ to $11^{\circ} \mathrm{W}$ (Fig. 1), a representative cell for the physical forcing that determines the hydrographic and biogeochemical conditions in the region (e.g. ÁlvarezSalgado et al. 2002). Positive values of UI indicate upwelling-favourable conditions whereas negative values indicate downwelling-favourable conditions. Further numerical details can be found in GonzálezNuevo et al. (2014). In this study, values of UI were averaged over $15 \mathrm{~d}$ prior to each sampling date. These values represent the accumulated effect of the main meteorological and hydrological factors on phytoplankton dynamics as shown by other studies in the Galician upwelling (e.g. Nogueira et al. 1997).

\section{Volumetric cell size and functional traits}

Cell size, expressed as cell biovolume (in $\mu^{3}{ }^{3}$, for each species was estimated in some samples distributed over all seasons from measurements of dimensions of 30 to 100 cells under the microscope, assigning a certain geometric shape to each species (see Huete-Ortega et al. 2010). In the case of colonial species, only the volumetric size of individual cells was considered. Cell biomass (in pg C) was estimated from biovolume by using conversion equations from the literature (Menden-Deuer \& Lessard 2000). Species biomass was calculated by multiplying species abundance by cell biomass. Total biomass (obtained as the sum of the biomass of all species) was significantly correlated with water column-integrated chl $a$ recorded at this station (see Fig. S2 in the Supplement). Volumetric cell size values are provided in Table S1.

Volumetric cell size is considered as a meta-trait (see above) that can determine other physiological traits and tradeoffs across traits (Edwards et al. 2011, Barton et al. 2013a). Therefore, in order to complement the analysis of cell size effects (see below), we obtained data on other traits from recently published compilations on laboratory-measured functional traits. In particular, maximum growth rates $\left(\mu_{\max }\right.$ in $\mathrm{d}^{-1}$ ) were obtained from temperature dependent growth rates assembled in Thomas et al. (2016). This parameter measures the species' maximum growth rate as obtained from fitting a thermal tolerance curve characterizing the growth responses to changes in temperature. Maximum growth rates could be obtained by means of fitting other models, for instance, the Droop model of phytoplankton growth (Edwards et al. 2012), or using data from growthirradiance experiments (Edwards et al. 2015a). However, in order to be coherent, we only used data from Thomas et al. (2016) and followed the quality control measures specified by those authors. Additionally, the optimum temperatures $\left(T_{\mathrm{opt}}\right.$ in $\left.{ }^{\circ} \mathrm{C}\right)$ for maximizing growth rates were also extracted from the same source. Furthermore, nutrient utilization traits are frequently used to link phytoplankton ecophysiology and population dynamics (e.g. Edwards et al. 2013). Thus, we collated nutrient utilization trait data from Edwards et al. (2015b). More specifically, we used the maximum rate of nitrogen uptake $\left(V_{\max }^{N}\right.$ in $\mu \mathrm{mol}$ cell $^{-1} \mathrm{~d}^{-1}$ ) because measurements for $V_{\max }^{N}$ were available for a large number of our species. This parameter measures the maximum cell-specific nutrient uptake rate of the Michaelis-Menten model of nutrient uptake. In total, we obtained $\mu_{\max }$ and $T_{\mathrm{opt}}$ data for 20 species and $V_{\max }^{N}$ data for 8 species (Table S1). In those cases where multiple trait data were available for a given species we computed averages. It should be noted that the use of traits obtained from laboratory experiments has limitations. In particular, we were only able to obtain traits for a small number of taxa because quantitative physiological traits are usually not known for all species. This occurs because researchers tend to study certain species instead of a random sample from natural communities. Therefore, this fact may skew results, though we believe that this approach does provide new insights into the phytoplankton ecology of the NW Iberian upwelling system.

\section{Statistical analyses}

Seasonal and long-term trends in UI, physical and biogeochemical variables, and total abundance and biomass of phytoplankton in the euphotic layer were evaluated using generalised additive mixed models (GAMMs; Wood 2006) as follows:

$$
Y_{t}=\alpha+f_{1}\left(\operatorname{DoY}_{t}\right)+f_{2}\left(\text { Days }_{t}\right)+\varepsilon_{t}
$$

where the response variable, $Y_{t}$ would be recorded on sampling day $t$. $\alpha$ is an intercept, and $f_{\text {ns }}$ are 
1-dimensional non-parametric smoothing functions describing the effect of day of the year (DoY) and days (consecutive days from 1989 to 2010). The smoothing functions were fit by a penalised cyclic cubic regression spline and a cubic regression spline for DoY and days, respectively, and with a maximum of 6 and 3 knots (Wood 2006). Observations were made sequentially over time, thus errors $\left(\varepsilon_{t}\right)$ might not be independent. Therefore, a specific correlation structure was added to the formulation. In the case of the UI, observations were regularly spaced, thus an auto-regressive model of order 1 allowing for withinyear auto-correlation between the residuals was evaluated. By contrast, observations of biogeochemical variables, total abundance and biomass were irregularly spaced, thus, in those cases the inclusion of an exponential spatial correlation model that can accommodate the imbalance in time was tested (see Tables S2 \& S3 in the Supplement). Model fitting improvement was evaluated using likelihood ratio tests (Pinheiro \& Bates 2000).

Time-series of phytoplankton abundance typically contain a large proportion of zeros due to naturally large fluctuations in abundance and non-detection of rare species (Fig. S1). This results in distributions where the response variable takes values from zero to infinity, exhibiting a large probability of mass at zero. To account for this distribution, we used a semiparametric discrete-continuous mixture model approach with the zero-adjusted lognormal (ZALN) distribution, which is useful when processes of occurrence and abundance can be influenced by different factors (e.g. Fox et al. 2000, Edwards et al. 2013). The model formulation for a variable, $Y$, that follows this distribution was implemented as a 2-stage conditional approach in which the presence/absence of biomass was modelled as a binary response assuming a Bernoulli distribution for the expected probability of presence for each species, $i$, at time $t\left(\pi_{t}^{i}\right)$ as follows:

$$
\begin{aligned}
\log \left(\frac{\pi_{t}^{i}}{1-\pi_{t}^{i}}\right)= & \alpha^{i}+h^{i}\left(\operatorname{DoY}_{t}\right)+\beta_{1}^{i} \text { Days }_{t}+\beta_{2}^{i} \mathrm{SST}_{t} \\
& +\beta_{3}^{i} \mathrm{NIT}_{t}+\beta_{4}^{i} \mathrm{UI}_{t}
\end{aligned}
$$

The abundance, conditional on presence, for each species $i$ at time $t\left(\mu_{t}^{i}\right)$ was modelled as a continuous response assuming a lognormal distribution as follows:

$$
\begin{aligned}
\log \left(\mu_{t}^{i}\right)= & \alpha^{i}+h^{i}\left(\operatorname{DoY}_{t}\right)+\beta_{1}^{i} \text { Days }_{t}+\beta_{2}^{i} \mathrm{SST}_{t} \\
& +\beta_{3}^{i} \mathrm{NIT}_{t}+\beta_{4}^{i} \mathrm{UI}_{t}+\varepsilon_{t}^{i}
\end{aligned}
$$

For both the binary and continuous parts we used the same set of predictors, where DoY is the day of the year and $h$ is a 1-dimensional non-parametric smoothing function fit by a penalised cyclic cubic regression spline with a maximum of 6 knots. Days is the time trend (i.e. consecutive days from 1989 to 2010), SST is sea surface temperature, NIT is the nutrient concentration (i.e. nitrate concentration integrated in the upper $40 \mathrm{~m}$ ), and UI is the coastal upwelling, which were modelled parametrically with slopes denoted by $\beta_{s}$. $\alpha$ is an intercept, and $\varepsilon_{t}$ is a vector of errors assumed to be independent and normally distributed. For simplicity, the 2 components of the ZALN model are called occurrence (presence/ absence, PA) and abundance (positive counts, PO) models. There were no apparent correlations between model predictors (variance inflation factors $<2$ ); and, before running the model, the 3 environmental variables were standardized to have zero mean and unit variance. Pearson residuals from each ZALN model were evaluated for model assumptions.

In order to assess the importance of cell size and functional traits in structuring the individual responses to the predictors, the parametric coefficients from Eqs. (2) and (3) (i.e. $\beta_{s}^{i}$ ), defining each species $i$ trend in abundance and specific responses to SST, nitrate concentration and upwelling strength, were related to the species $i$ cell biovolume as follows:

$$
\beta_{i}=a+b\left(\text { Biovolume }_{i}\right)+\varepsilon_{i}
$$

To fit Eq. (4), we used model II regressions by the standardized (or reduced) major-axis method (SMA; Warton et al. 2012). Similarly, parametric coefficients from Eqs. (2) and (3) were related to the laboratory-measured functional traits. Prior to analysing these later relationships, functional traits (i.e. $\mu_{\max }$ $T_{\text {opt }}$ and $\left.V_{\max }^{N}\right)$ were adjusted to account for cell size - that is, we used as predictors the residuals of the SMA regressions of each trait with cell biovolume.

All treatment of data and analyses were performed with the software R v.3.4.3 (R Core Team 2017) using the packages 'mgcv 1.8-22' (Wood 2006), 'nlme 3.1131' (Pinheiro \& Bates 2000), and 'smatr 3.4-3' (Warton et al. 2012).

\section{RESULTS}

\section{Biogeochemical patterns}

Coastal winds at the latitude of the NW Iberian Peninsula caused upwelling during spring and summer (March to October), whereas in autumn and winter (November to February) there was a domi- 

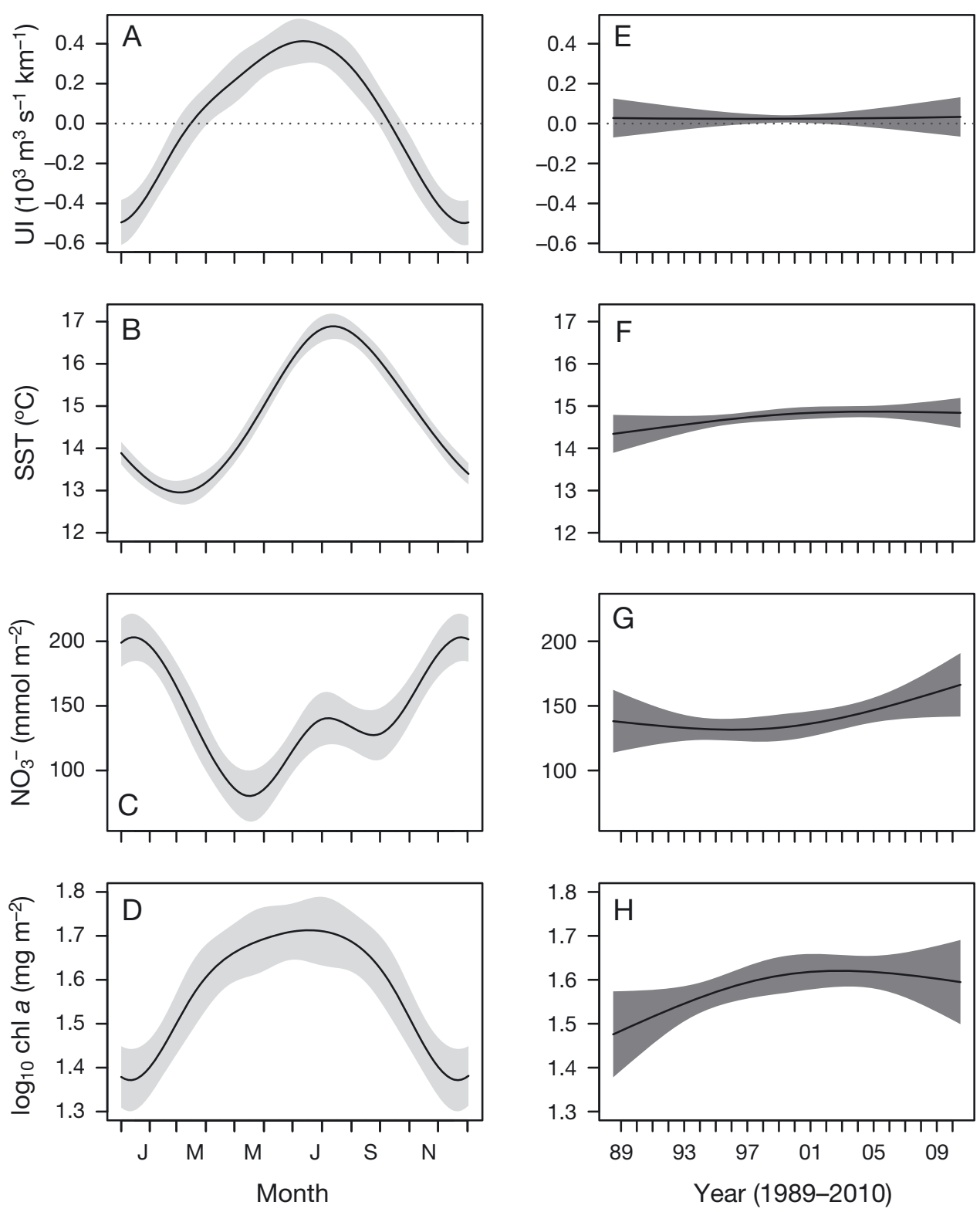

Fig. 2. Seasonal and long-term trends of the $(A, E)$ upwelling index, $(B, F)$ sea surface temperature, $(C, G)$ euphotic layer-integrated nitrate and $(\mathrm{D}, \mathrm{H})$ water-column integrated chl a during the study period. Shaded areas indicate $95 \% \mathrm{CI}$ around the main effects; light and dark grey shading highlight the statistical or non-statistical significance of a particular effect, respectively (see numerical results for each model in Table S2 in the Supplement at www.int-res.com/articles/suppl/m596p033_ supp.pdf). Note that chl a was $\log _{10}$ transformed prior to analysis

nance of downwelling (Fig. 2A, Table S2). The hydrography at the sampling station also showed strong seasonal patterns, though varying in shapes. While SST peaked in August (Fig. 2B, Table S2), the integrated nitrate concentration in the euphotic layer reached maximum values during autumn and winter (Fig. 2C, Table S2), and the water column-integrated chl a showed a more extended maximum over spring and summer months (Fig. 2D, Table S2). On the other hand, there were no significant long-term trends for any of these variables during the $22 \mathrm{yr}$ study period (Fig. 2E-H, Table S2).

Regarding total phytoplankton abundance and biomass, strong seasonal patterns were also observed, reaching a maximum in July and August (Fig. 3A,B). The long-term trend was similar for both variables, though not statistically significant (Fig. 3C,D, Table S3). 

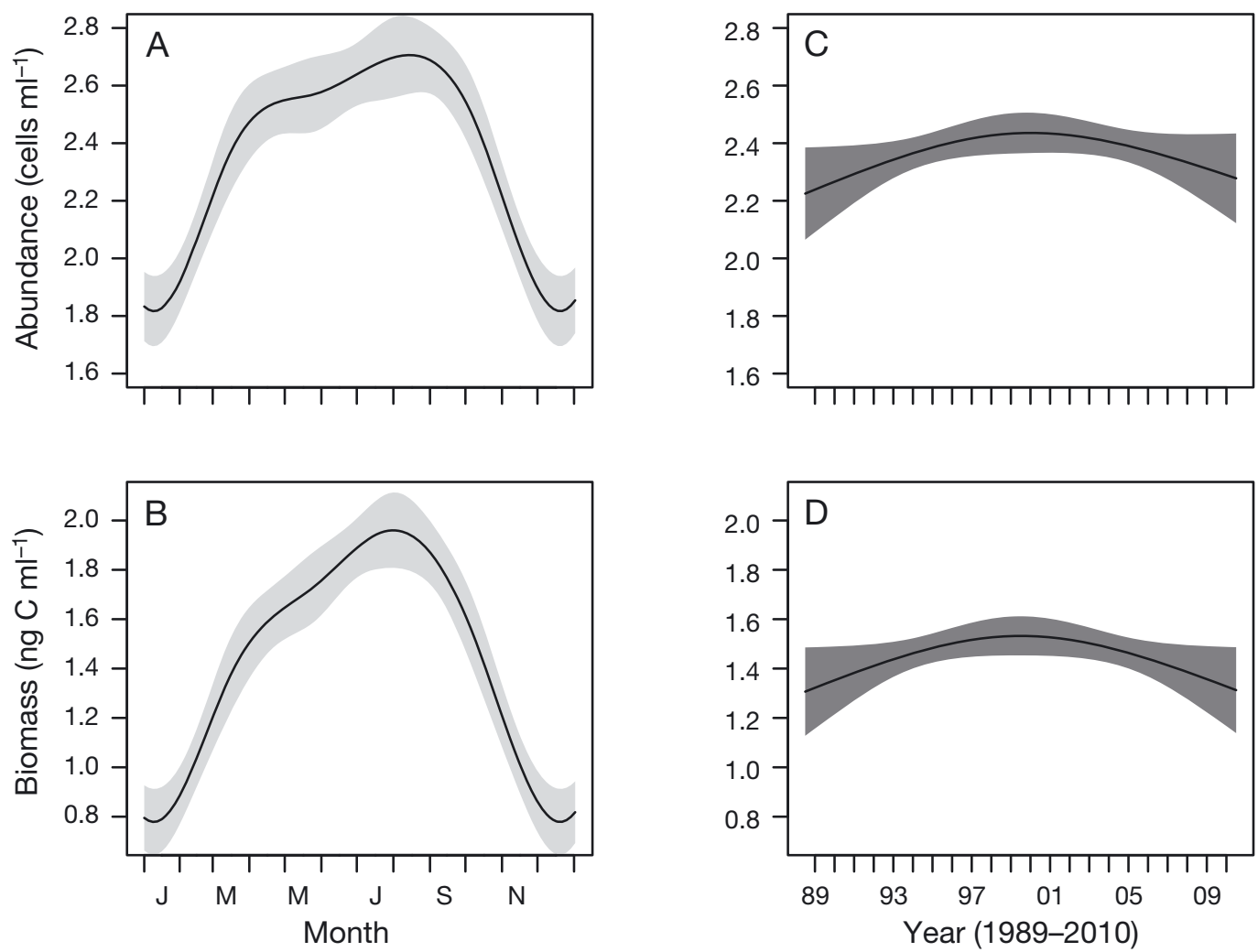

Fig. 3. Seasonal and long-term trends of the $(A, C)$ total abundance and $(B, D)$ total biomass during the study period. Shaded areas indicate $95 \%$ CI around the main effects; light and dark grey shading highlight the statistical or non-statistical significance of a particular effect, respectively (see numerical results for each model in Table S3 in the Supplement). Note that total abundance and total biomass were $\log _{10}$ transformed prior to analysis

\section{Species-specific models}

The set of 54 species analysed comprised various phytoplankton groups including 35 diatom taxa and 13 dinoflagellate taxa as the main taxonomic groups within the community (Table S1). Diatoms were numerically dominant, with Chaetoceros socialis showing the largest abundance. Regarding dinoflagellates, Heterocapsa niei was the species with the highest cellular abundance. In addition, Cryptophyceae was the most abundant taxon among the other phytoplankton groups (Table S1). In general, all species showed peaks and troughs in abundance over the studied period (Fig. S1) and annual cycles in most instances. As such, the occurrence model revealed heterogeneous trends among species during the year (Fig. S3), with some taxa having a higher probability of occurrence in spring and summer months (e.g. species 1, Asterionella glacialis; or species 34, Phaeocystis pouchetii), and others appearing mainly in winter (e.g. species 18, Dictyocha fibula; or species 30, Navicula transitans). Regarding the abundance model, most species showed clear sea- sonal cycles with higher abundances in spring and summer months; however, a few species were more abundant in autumn and winter, while others did not show any apparent seasonality (Fig. S4). Pearson residuals from the individual models did not show any significant patterns (Figs. S5-S7).

Long-term changes in occurrence were variable across species, with 9 out of 13 species of dinoflagellates and 7 out 35 species of diatoms showing positive slopes in the occurrence model, indicating higher probabilities of occurrence through time (Fig. S8A). When present, most species tended to increase in abundance during the study period, with the exception of 13 species of diatoms, 4 dinoflagellates and Cryptophyceae, which showed decreasing trends (Fig. S8E). The effect of SST was heterogeneous in both the occurrence and abundance sub-models. Most dinoflagellates, but also 21 diatoms, showed positive slopes, indicating a higher probability of occurrence in warmer waters (Fig. S8B), whereas when present, abundance of most species tended to decrease when SST was higher (Fig. S8F). Regarding nitrate concentration and UI, the responses in the oc- 

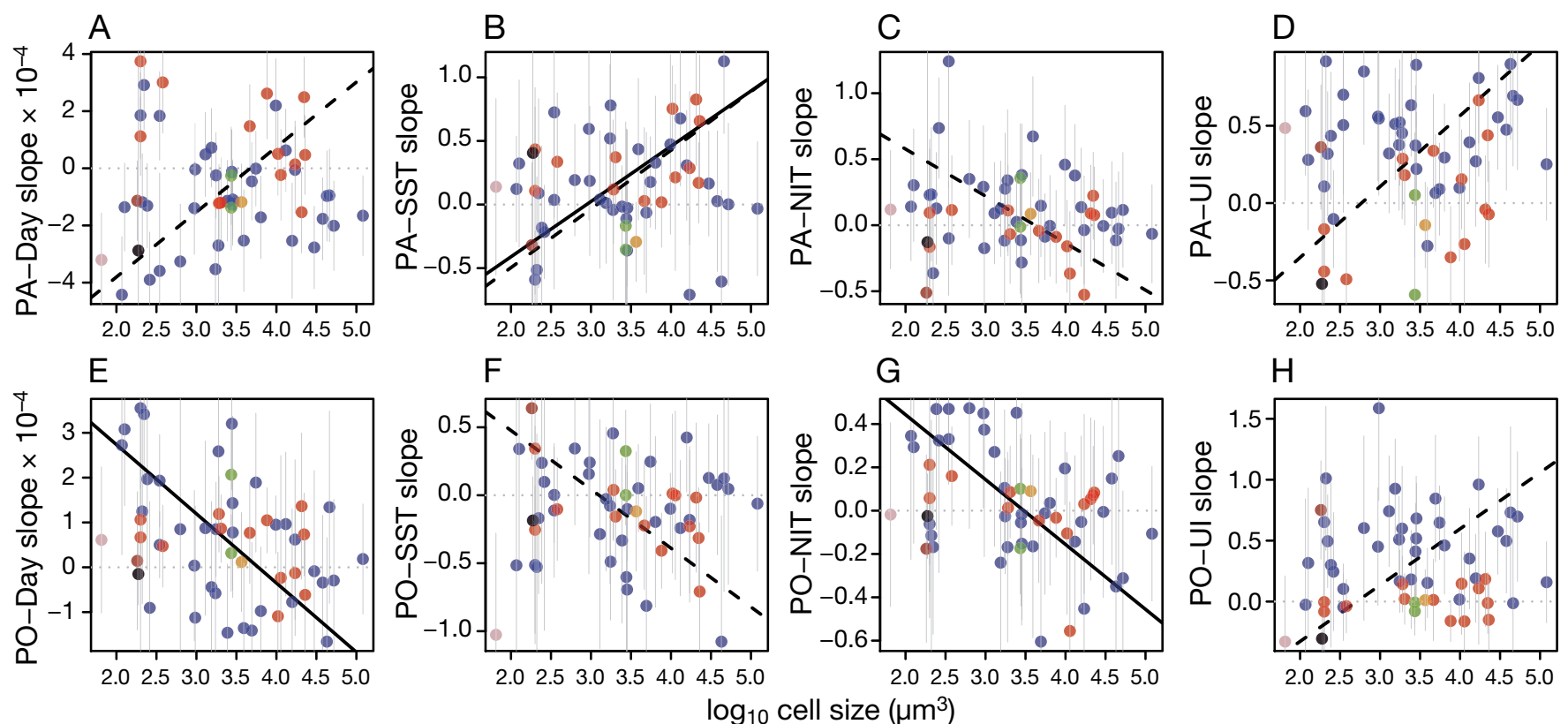

Fig. 4. Relationships between volumetric cell size and species-specific slopes for the (A-D) occurrence (PA) and (E-H) abundance (PO) models. Lines are included for reference and show regressions fit by the standardized major-axis method (SMA). Solid lines indicate that the correlation is statistically significant. In (B), the regression indicated by the solid line was computed excluding the 2 extreme cases that appear in the lower right hand side. Numerical results for each model are shown in Table S4, and colour codes as in Fig. S8 in the Supplement

currence sub-model were mostly positive, indicating that the probability of occurrence increased when both nitrate concentration (Fig. S8C) and upwelling strength (Fig. S8D) were higher. Furthermore, the abundance model indicated heterogeneous responses to changes in nitrate concentration, with nearly the same number of species with negative or nearzero slopes as species with positive slopes (Fig. S8G), and a majority of positive responses to an increase in the UI with steeper slopes for most taxa but particularly for diatom species (Fig. S8H).

\section{Role of cell size}

The distribution of the species' responses to the environment as a function of volumetric cell size was strongly heterogeneous, though model II regressions revealed some patterns (Fig. 4, Table S4). In particular, the lowest probabilities of occurrence over time were observed only for the smaller species (Fig. 4A). However, when present, abundance of smaller species tended to increase more than larger species during the studied years (Fig. 4E). Additionally, on the one hand, there were positive and negative trends between SST (Fig. 4B) and nitrate concentration (Fig. 4C) with cell size in the occurrence sub-models, indicating a higher probability of occurrence for smaller species when SST was cooler and nitrate con- centration was higher (Table S4). On the other hand, when present, the abundance of smaller species showed more positive responses to increases in SST (Fig. 4F) and nitrate concentration (Fig. 4G). Finally, the responses to upwelling intensity for both the occurrence (Fig. 4D) and abundance (Fig. 4H) models were strongly heterogeneous along the range of cell size without showing any clear pattern.

\section{Role of functional traits}

Functional traits obtained from laboratory experiments for some of the species studied here scaled with cell size (Table S5). Maximum growth rates (Fig. S9A) and optimum temperature for growth (Fig. S9B) decreased with increasing cell size, whereas the maximum rate of nitrogen uptake tended to increase with cell size (Fig. S9C). In turn, functional traits adjusted for cell size also suggested certain patterns in speciesspecific responses to environmental drivers, though not in individual long-term trends (Tables S6 \& S7). First, the probabilities of occurrence over the study period (Fig. 5A) and changes in abundance over time (Fig. 5D) were strongly heterogeneous along the range of growth rate and did not show a significant relationship with this trait. Second, regarding the environmental individual responses, species that had greater growth rates also had higher probabilities of 

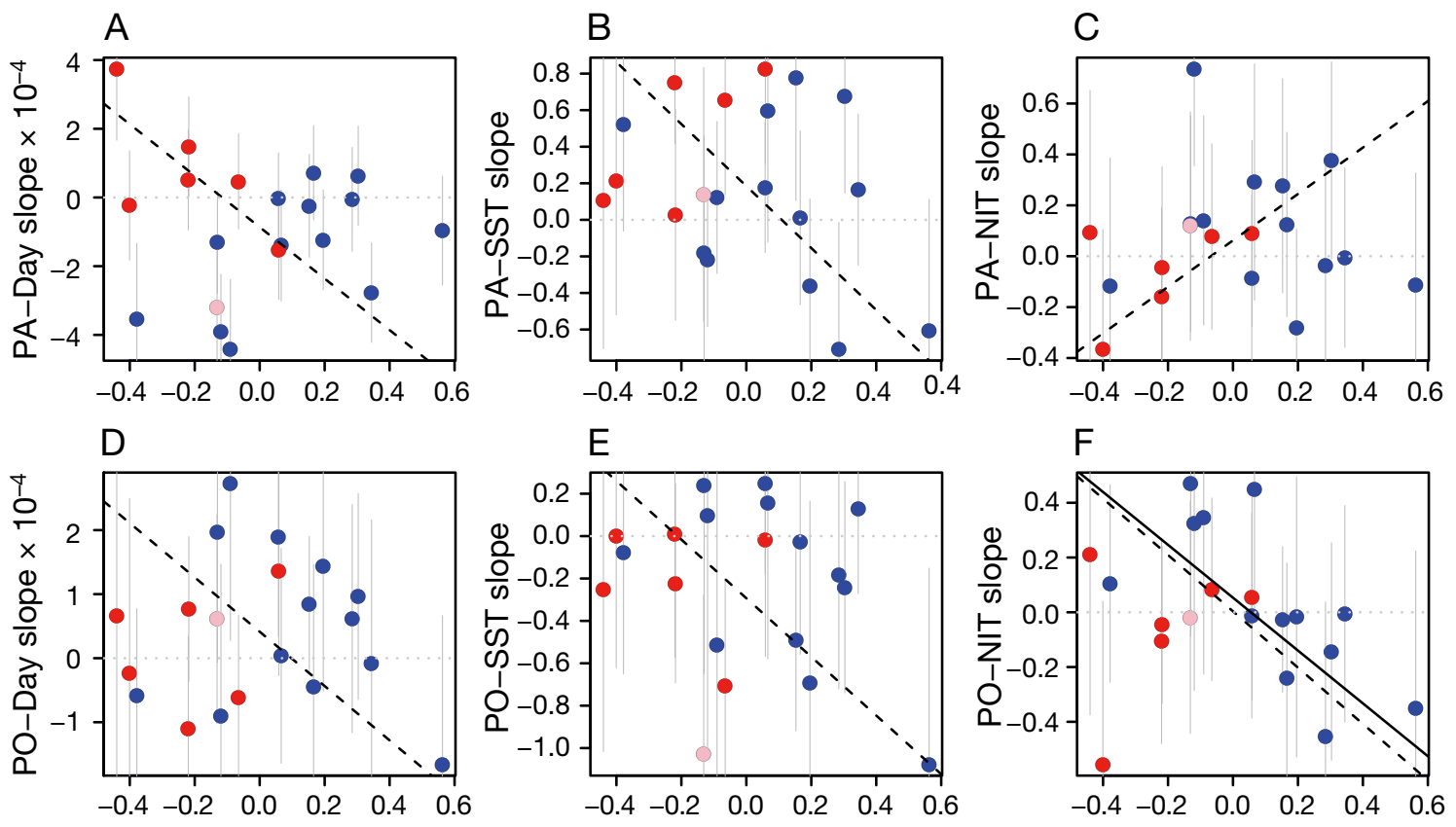

Cell size-corrected $\mu_{\max }$

Fig. 5. Relationships between volumetric cell size-adjusted growth rate $\mu_{\max }\left(\mathrm{d}^{-1}\right)$ and species-specific slopes for $(\mathrm{A}, \mathrm{D})$ time, $(B, E)$ sea surface temperature $(\mathrm{SST})$ and $(\mathrm{C}, \mathrm{F})$ nitrate concentration for the $(\mathrm{A}-\mathrm{C})$ occurrence and $(\mathrm{D}-\mathrm{F})$ abundance models. Lines are included for reference and show regressions fit by the standardized major-axis method (SMA) method. In (F), the regression indicated by the solid line was computed excluding the extreme case that appears in the lower left hand side. Numerical results for each model are shown in Table S6, and colour codes as in Fig. S8 in the Supplement

occurrence when SST was cooler (Fig. 5B), and when nitrate concentration (Fig. 5C) and especially upwelling intensity (Fig. 6A) increased. Furthermore, the abundance of species that had greater growth rates showed more negative responses to increases in SST (Fig. 5E) and nitrate concentration (Fig. 5F), and more positive responses to increases in the UI (Fig. 6B).

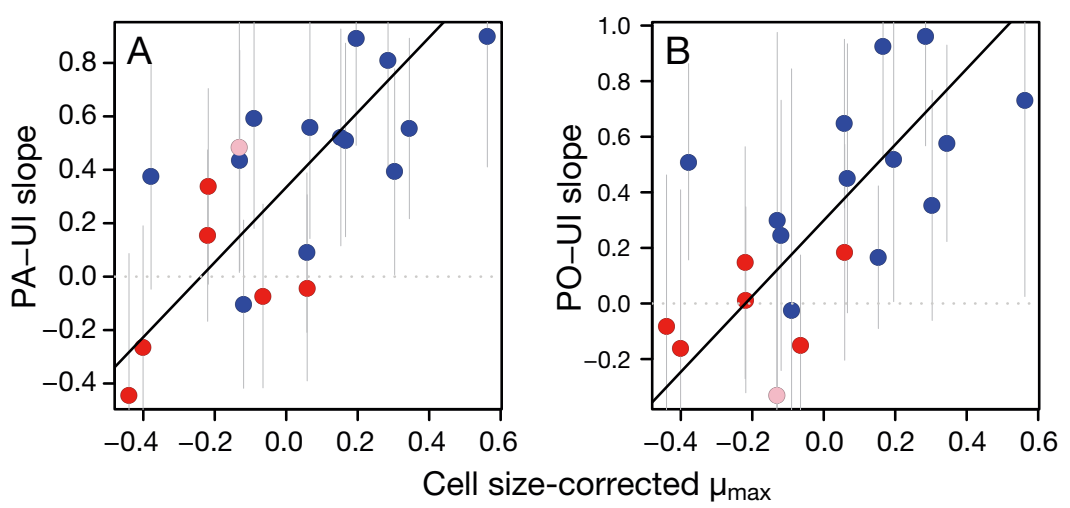

Fig. 6. Relationships between volumetric cell size-adjusted growth rate $\mu_{\max }$ $\left(\mathrm{d}^{-1}\right)$ and species-specific response to the upwelling intensity for the (A) occurrence (PA) and (B) abundance (PO) models. Lines are included for reference and show regressions fit by the standardized major-axis method (SMA) method. Numerical results for each model are shown in Table S6, and colour codes as in Fig. S8
In addition, on the one hand, species with higher values of optimum temperature for growth (Fig. 7A) and lower maximum rates of nitrogen uptake (Fig. 7B) had higher probabilities of occurrence when SST and upwelling intensity increased. On the other hand, when present in the water, the abundance of species with higher maximum rates of nitrogen uptake was also more responsive to increases in nitrate concentration (Fig. 7C), whereas increases in abundance with upwelling intensity were higher for species with lower rates of nitrogen uptake (Fig. 7D).

\section{DISCUSSION}

\section{Heterogeneous patterns in phytoplankton}

Phytoplankton species sharing a certain 'life-form' and strategies related to the uptake of nutrients and persistence in the photic layer are generally of the same taxonomic group (e.g. Margalef 1978), and such generalisa- 

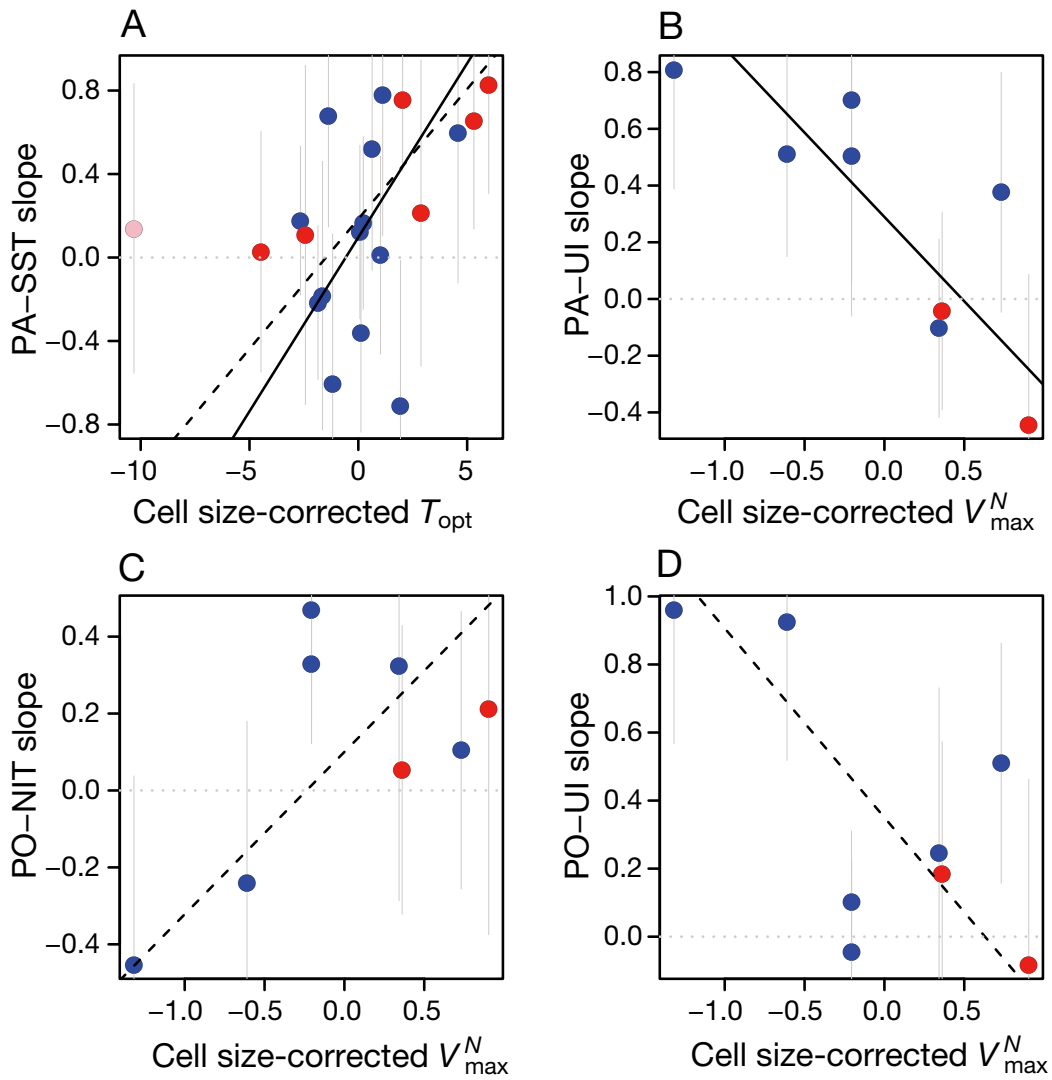

Fig. 7. Relationship between (A) volumetric cell size-adjusted optimum temperature for growth $T_{\text {opt }}$ and species-specific responses to sea surface temperature (SST) for the occurrence (PA) model; (B) cell size-adjusted maximum rate of nitrogen uptake $\left(\mu \mathrm{mol} \mathrm{cell}^{-1} \mathrm{~d}^{-1}\right)$ and species-specific responses to upwelling index (UI) for the occurrence model; (C) cell size-adjusted maximum rate of nitrogen uptake and species-specific responses to nitrate concentration for the abundance (PO) model; and (D) cell size-adjusted maximum rate of nitrogen uptake and species-specific responses to UI for the abundance model. Lines are included for reference and show regressions fit by the standardized major-axis method (SMA) method. In (A), the regression indicated by the solid line was computed excluding the extreme case that appears in the mid left hand side. Numerical results for each model are shown in Table S7, and colour codes as in Fig. S8

tions lead to the common assumption of certain functional responses usually ascribed to those groups. This separation into broad categories (e.g. diatoms and flagellated groups mostly identified with dinoflagellates) has been and is still used to analyse phytoplankton community structure, and particularly to interpret changes related to climate (e.g. Leterme et al. 2005, Pérez et al. 2010, Barton et al. 2013b, 2015). However, several authors have suggested that there is a continuum of species responses to changes in the environment (Margalef 1978, Reynolds 1997, Nogueira et al. 2000), and today there is growing evidence that the trends observed in individual species' abundance or biomass might not follow any general pattern related to these broad taxonomical groupings
(Mutshinda et al. 2013, Bode et al. 2015a). In fact, recent analyses highlight the large diversity of species-specific patterns that preclude the use of trait means by taxonomic groups or communities to predict the dynamics of individual species (Edwards 2016, Mutshinda et al. 2016).

Across-system comparisons in estuarine and coastal waters have revealed that phytoplankton blooms are typically dominated by one or a few species that are generally of large size and able to escape grazing (Irigoien et al. 2004, Carstensen et al. 2015), though no general rules for responses to environmental forcing can be outlined. This suggests that site-specific bloom dynamics should be regulated by species-explicit responses to environmental conditions (Carstensen et al. 2015). This diversity in responses would be ultimately determined by the interspecific variation in functional traits that will influence growth rates during the onset of the blooms (Lewandowska et al. 2015). Thus, the mechanisms underlying the complex structure of phytoplankton communities could be explained at least in part by the physiological and ecological characteristics of each species (e.g. Klais et al. 2017). Hence, community assembly can, to some extent, be predictable using a small group of functional traits, at least for regions with short and well-defined productive periods (e.g. the Western English Channel; Edwards et al. 2013, Edwards 2016). However, this interaction between environmental conditions and species physiology and traits for structuring the community is not well understood for phytoplankton assemblages in coastal upwelling ecosystems in which most of the variability in abundance is ascribed to stochastic processes (Bode et al. 2009).

The results of our study confirm the conclusions of a previous analysis of the annual fluctuations in abundance for the same set of species (Bode et al. 2015a), as no clear patterns emerged for diatoms, dinoflagellates or other groups, belying the implicit assumption of homogeneous responses to climate by species belonging to the same taxonomic group in a highly perturbed coastal upwelling system. Rather, the species studied in this region clustered according 
to the long-term pattern without any correspondence with taxonomical groups. The present study extends those results by providing insights on the influence of functional traits in structuring the abundance responses by individual species to environmental conditions.

\section{Phytoplankton changes in the NW Iberian upwelling}

The upwelling regime in this region is characterized by an intermittent inflow of cold and nutrient-rich subsurface waters followed by relaxation or downwelling events (Álvarez-Salgado et al. 2002). Phytoplankton populations occurring in these waters are adapted to those upwelling-relaxation-downwelling episodes, with specific assemblages characterizing the different annual oceanographic stages (Casas et al. 1997, 1999). Microflagellates are the dominant group during most of the year, while diatoms predominate over dinoflagellates during bloom periods (Casas et al. 1999). However, besides this general framework, species-specific reactions to temperature, nutrient inputs and upwelling intensity are expected. As such, the occurrence and abundance of the group of species analysed here showed heterogeneous responses to environmental drivers. In particular, the occurrence of most species seemed to be favoured when SST was warmer and when both nitrate concentration and upwelling intensity were higher, with relationships with nitrate and upwelling being more important for diatoms which showed more positive slopes. Additionally, the abundance of species was more sensitive to changes in the upwelling intensity, especially for diatoms, whereas nitrate concentration played a minor role in affecting abundance for the majority of species, and responses to SST where both negative and positive. For instance, spring blooms are generally dominated by Chaetoceros socialis, while Leptocylindrus danicus dominated summer blooms related to upwelling (Casas et al. 1999). The underlying functional responses of these species can be found in our analysis in the form of a negative slope in the abundance-SST and abundance-nitrate relationships for the former species while the latter showed positive slopes. Both species showed positive responses of similar magnitude to upwelling intensity, thus modulated by their specific responses to temperature and nitrate. This underlies the importance of the response of individual species to seasonal variations in photoperiod, as the light would be limiting for phytoplankton growth during spring (Varela 1992).

\section{Role of cell size}

When using cell size to explain the structure of the responses to environmental drivers we found that occurrence of smaller species tended to be favoured when SST was cooler and when nitrate concentration was higher. Correspondingly, when present in the water, smaller species also showed larger increases in abundance (i.e. more positive slopes) with higher values of SST and nitrate concentration. Overall, these results suggest that smaller species are more responsive to decreases in temperature and especially increases in nitrate concentration compared to larger species under non-limiting conditions where nutrients are provided in sufficient amounts by either upwelling of Eastern North Atlantic Central Water or by inputs of nutrients mineralised in the bottom shelf. In support of this, Lomas \& Glibert (2000) reported half-saturation values for nitrate that were higher for smaller than larger diatom species in experimental cultures, while Bode et al. (2015a), applying non-linear models to a subset of the series used in the present study, found in most cases a saturating type of relationship between species abundance and nitrate concentrations.

The larger occurrence and increase in abundance of smaller species (note that our size range spanned

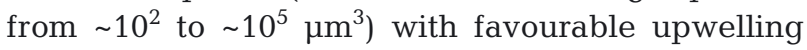
conditions agrees with the unimodal distribution of phytoplankton biomass with the size of bloom-forming species (Marañón 2015). Such distribution has been attributed to a size-dependent tradeoff between resource acquisition and the potential rate of internal metabolism (Ward et al. 2017). This implies that large changes in the size composition of the phytoplankton community in the study region would not be expected within the current range of upwelling intensity and nutrient supply. However, intraspecific variations in many traits, including cell size, could ultimately determine the structure of communities, as shown by models (e.g. Menden-Deuer \& Rowlett 2014). While we used only average sizes per species, a more detailed analysis could be done using the actual size of cells in the different environmental situations. Including a higher number of traits and species may provide further insights into the apparent dominance of species with cells of intermediate sizes during blooms (Marañón 2015).

Despite the structure of the responses to environmental changes showing certain patterns along the range of cell size, the explanatory power of this trait was very low and inconclusive in some instances, suggesting that traits other than size would interact 
with cell size causing the change in variance on the distribution of the species-specific relationships with upwelling intensity, SST and nutrients. An invariant size scaling of phytoplankton abundance across ecosystems suggests that the cells were able to overcome the limitations arising from cell size by diverse adaptive strategies (Cermeño et al. 2006). For instance, some species may increase in size by using non-limiting substrates to escape grazing (Thingstad et al. 2005).

\section{Role of functional traits}

The relationships between $\mu_{\max }, T_{\text {opt }}$ or $V_{\max }^{N}$ and cell size for our set of species were consistent with previous studies (e.g. Edwards et al. 2011, Marañón 2015). Accounting for cell size in these traits allowed us to provide complementary contributions of traits other than cell size in explaining individual responses to the environment. In this regard, on the one hand, fast-growing species showed higher probability of occurrence in cooler waters. Correspondingly, species with higher optimum temperatures for growth had higher probabilities of occurrence in warmer waters. On the other hand, the occurrence of fast-growers was higher when nutrients and especially upwelling intensity increased. When present in the water, the abundance of fast-growers was again more dependent on upwelling intensity, whereas slow-growers responded more positively to increases in nitrate concentration. This corresponds well when considering the nitrogen uptake rate. Abundance of species with more positive responses to nitrate concentration also had higher rates of nitrogen uptake. Furthermore, the occurrence and abundance of species with lower rates of nitrogen uptake were favoured when upwelling intensity increased. In conjunction, this all suggests that smaller species that grow at faster rates though are less efficient in taking up nitrogen respond rapidly in upwelling conditions with increases in occurrence and abundance. These results concur with the fact that in coastal upwelling zones the nutrient supply to the euphotic layer occurs through intermittent pulses, thus favouring the proliferation of species of intermediate sizes with higher growth rates (Varela 1992, Marañón 2015). Nitrate affinity scales isometrically with cell volume (Marañon et al. 2013), but this relationship also has implications for the scaling of kinetic parameters with other traits, such as the number of transporters required in the cell membrane or the handling time required (Beltrán-Heredia et al. 2017). As mentioned earlier, the differential dominance of certain species in spring (C. socialis) or summer blooms (L. danicus) under different nutrient and temperature conditions but similar upwelling regimes suggests a major role of additional traits related to nutrient processing (Varela 1992).

\section{Species-specific long-term trends}

The analysis of the long-term trends in abundance also revealed high interspecific variation, as previously shown (Bode et al. 2015a). Remarkably, most dinoflagellate species exhibited an increase in occurrence and abundance during the study period, whereas increases and decreases in occurrence and abundance of diatoms where more evenly distributed across species during the last decades. A dominance of dinoflagellates (considered as a homogeneous group) is expected in warmer waters because of their greater responsiveness to warming compared to diatoms (Finkel et al. 2010, Mutshinda et al. 2016). We may speculate that this could be due to a plausible scenario in Galician waters, given that the occurrence of the studied dinoflagellates was more sensitive to increases in temperature, and taking into account the observed warming for the Galician coast (Santos et al. 2012). Regarding the contribution of traits in structuring the changes in occurrence and abundance over time, larger species with lower growth rates tended to have higher probabilities of occurrence in recent years; however, the smaller species were the ones that showed greater increases in abundance over the study period, concurring with the postulated increase in importance of smaller primary producers in a warmer ocean (Morán et al. 2010).

\section{CONCLUSIONS}

The response of individual phytoplankton taxa to the environmental drivers in the Galician upwelling was widely heterogeneous even for species belonging to the same taxonomic group. Therefore, our results provide further evidence for limitations of analyses based on patterns observed in broad groups (e.g. diatoms vs. dinoflagellates) when interpreting and predicting changes in the organization of phytoplankton communities as a result of key environmental drivers, in particular those related to climate change. The influence of cell size in the individual responses to environmental drivers was relatively 
minor, though it suggested that smaller species would be favoured under upwelling conditions. The heterogeneity in individual responses to the environmental drivers along the whole size range studied here implies the existence of tradeoffs between multiple traits affecting phytoplankton abundance. Functional traits, such as maximum growth rate and maximum rate of nitrogen uptake, once adjusted for cell size, indicated that species with higher growth rates and lower rates of nitrogen uptake had a greater chance of success and increased abundance in upwelling-favourable conditions. In conjunction, these results support the dominance of species of intermediate size during blooms in this upwelling region. Additionally, the results of this study align with recent evidence highlighting the need to better quantify traits, and tradeoffs among traits, to disentangle the mechanisms implied in the speciesspecific responses to the environment in a fluctuating upwelling system, and how these responses feed back into the biogeochemical cycles of a changing coastal ocean. Traits averaged or integrated across communities or groups (e.g. diatoms, dinoflagellates) are useful when analysing community structure and ecosystem function, but may lead to oversimplified interpretations of the underlying responses of individual species, as shown in this and other studies.

Acknowledgements. We acknowledge the dedication of a large number of technicians, crew members and scientists who contributed to the observational time series project RADIALES conducted and funded by the Instituto Español de Oceanografía (www.seriestemporales-ieo.com). J.O. was supported by a 'Junta para la Ampliación de Estudios' Fellowship (JAE-Doc programme 2011) from the CSIC and ESF. Dr. Kyle Edwards (University of Hawaii) provided valuable comments and data at different stages of development of this study; and 3 anonymous reviewers greatly helped to improve the manuscript.

\section{LITERATURE CITED}

Álvarez-Salgado XA, Beloso S, Joint I, Nogueira E and others (2002) New production of the NW Iberian shelf during the upwelling season over the period 1982-1999. Deep Sea Res I 49:1725-1739

* Bakun A, Black BA, Bograd SJ, García-Reyes M, Miller AJ, Rykaczewski RR, Sydeman WJ (2015) Anticipated effects of climate change on coastal upwelling ecosystems. Curr Clim Chang Rep 1:85-93

Barton AD, Pershing AJ, Litchman E, Record NR and others (2013a) The biogeography of marine plankton traits. Ecol Lett 16:522-534

Barton AD, Finkel ZV, Ward BA, Johns DG, Follows MJ (2013b) On the roles of cell size and trophic strategy in North Atlantic diatom and dinoflagellate communities. Limnol Oceanogr 58:254-266
Barton $\mathrm{AD}$, Finkel ZV, Ward BA, Johns DG, Follows MJ (2015) Physical controls of variability in North Atlantic phytoplankton communities. Limnol Oceanogr 60: 181-197

* Beltrán-Heredia E, Aksnes DL, Cao FJ (2017) Phytoplankton size scaling with nutrient concentration. Mar Ecol Prog Ser 571:59-64

* Bode A, Álvarez-Ossorio MT, Cabanas JM, Miranda A, Varela M (2009) Recent trends in plankton and upwelling intensity off Galicia (NW Spain). Prog Oceanogr 83:342-350

* Bode A, Anadón R, Morán XAG, Nogueira E, Teira E, Varela M (2011) Decadal variability in chlorophyll and primary production off NW Spain. Clim Res 48:293-305

* Bode A, Estévez MG, Varela M, Vilar JA (2015a) Annual trend patterns of phytoplankton species abundance belie homogeneous taxonomical group responses to climate in the NE Atlantic upwelling. Mar Environ Res 110:81-91

Bode A, Estévez MG, Varela M, Vilar JA (2015b) Phytoplankton abundance series (1989-2008) off A Coruña. PANGEA, https://doi.org/10.1594/PANGAEA.855901

* Carr ME (2001) Estimation of potential productivity in eastern boundary currents using remote sensing. Deep Sea Res II 49:59-80

* Carstensen J, Klais R, Cloern JE (2015) Phytoplankton blooms in estuarine and coastal waters: seasonal patterns and key species. Estuar Coast Shelf Sci 162:98-109

* Casas B, Varela M, Canle M, González N, Bode A (1997) Seasonal variations of nutrients, seston and phytoplankton, and upwelling intensity off La Coruña (NW Spain). Estuar Coast Shelf Sci 44:767-778

Casas B, Varela M, Bode A (1999) Seasonal succession of phytoplankton species on the coast of A Coruña (Galicia, northwest Spain). Bol Inst Esp Oceanogr 15:413-429

Cavender-Bares KK, Karl DM, Chisholm SW (2001) Nutrient gradients in the western North Atlantic Ocean: relationship to microbial community structure and comparison to patterns in the Pacific Ocean. Deep Sea Res I 48: 2373-2395

Cermeño P, Figueiras FG (2008) Species richness and cellsize distribution: size structure of phytoplankton communities. Mar Ecol Prog Ser 357:79-85

* Cermeño P, Marañón E, Harbour D, Harris RP (2006) Invariant scaling of phytoplankton abundance and cell size in contrasting marine environments. Ecol Lett 9: 1210-1215

Chassot E, Bonhommeau S, Dulvy NK, Mélin F, Watson R, Gascuel D, Le Pape O (2010) Global marine primary production constrains fisheries catches. Ecol Lett 13:495-505

* Chavez FP, Messié M (2009) A comparison of eastern boundary upwelling ecosystems. Prog Oceanogr 83:80-96

* Chavez FP, Messié M, Pennington JT (2011) Marine primary production in relation to climate variability and change. Annu Rev Mar Sci 3:227-260

Croll DA, Marinovic B, Benson S, Chavez FP, Black N, Ternullo R, Tershy BR (2005) From wind to whales: trophic links in a coastal upwelling system. Mar Ecol Prog Ser 289:117-130

* Doval MD, López A, Madriñán M (2016) Temporal variation and trends of inorganic nutrients in the coastal upwelling of the NW Spain (Atlantic Galician rías). J Sea Res 108: 19-29

*Edwards KF (2016) Community trait structure in phytoplankton: seasonal dynamics from a method for sparse trait data. Ecology 97:3441-3451 
Edwards KF, Klausmeier CA, Litchman E (2011) Evidence for a three-way trade-off between nitrogen and phosphorous competitive abilities and cell size in phytoplankton. Ecology 92:2085-2095

Edwards KF, Thomas MK, Klausmeier CA, Litchman E (2012) Allometric scaling and taxonomic variation in nutrient utilization traits and maximum growth rate of phytoplankton. Limnol Oceanogr 57:554-566

Edwards KF, Litchman E, Klausmeier CA (2013) Functional traits explain phytoplankton community structure and seasonal dynamics in a marine ecosystem. Ecol Lett 16: 56-63

Edwards KF, Thomas MK, Klausmeier CA, Litchman E (2015a) Light and growth in marine phytoplankton: allometric, taxonomic, and environmental variation. Limnol Oceanogr 60:540-552

Edwards KF, Klausmeier CA, Litchman E (2015b) Nutrient utilization traits of phytoplankton. Ecology 96:2311

Falkowski PG, Fenchel T, Delong EF (2008) The microbial engines that drive Earth's biogeochemical cycles. Science 320:1034-1039

Finkel ZV, Beardall J, Flynn KJ, Quigg A, Rees TAV, Raven JA (2010) Phytoplankton in a changing world: cell size and elemental stoichiometry. J Plankton Res 32:119-137

Fox CJ, O'Brien CM, Dickey-Collas M, Nash RDM (2000) Patterns in the spawning of cod (Gadus morhua L.), sole (Solea solea L.) and plaice (Pleuronectes platessa L.) in the Irish Sea as determined by generalized additive modelling. Fish Oceanogr 9:33-49

González-Nuevo G, Gago J, Cabanas JM (2014) Upwelling index: a powerful tool for marine research in the NW Iberian upwelling system. J Oper Oceanogr 7:45-55

Grasshoff K, Erhardt M, Kremling K (1983) Methods of seawater analysis, $2^{\text {nd }}$ edn. Verlag Chemie, Weinheim

* Harvey EL, Menden-Deuer S, Rynearson TA (2015) Persistent intra-specific variation in genetic and behavioral traits in the Raphidophyte, Heterosigma akashiwo. Front Microbiol 6:1277

*Hernández-Fariñas T, Soudant D, Barillé L, Belin C, Lefebvre A, Bacher C (2014) Temporal changes in the phytoplankton community along the French coast of the eastern English Channel and the southern Bight of the North Sea. ICES J Mar Sci 71:821-833

Huete-Ortega M, Marañón E, Varela M, Bode A (2010) General patterns in the size scaling of phytoplankton abundance in coastal waters during a 10-year time series. J Plankton Res 32:1-14

Irigoien X, Huisman J, Harris RP (2004) Global biodiversity patterns of marine phytoplankton and zooplankton. Nature 429:863-867

Klais R, Norros V, Lehtinen S, Tamminen T, Olli K (2017) Community assembly and drivers of phytoplankton functional structure. Funct Ecol 31:760-767

* Leterme SC, Edwards M, Seuront L, Attrill MJ, Reid PC, John AWG (2005) Decadal basin-scale changes in diatoms, dinoflagellates, and phytoplankton color across the North Atlantic. Limnol Oceanogr 50:1244-1253

Lewandowska AM, Striebel M, Feudel U, Hillebrand $\mathrm{H}$, Sommer U (2015) The importance of phytoplankton trait variability in spring bloom formation. ICES J Mar Sci 72: 1908-1915

Kitchman E, Klausmeier CA (2008) Trait-based community ecology of phytoplankton. Annu Rev Ecol Evol Syst 39: 615-639
Lomas MW, Glibert PM (2000) Comparisons of nitrate uptake, storage, and reduction in marine diatoms and flagellates. J Phycol 36:903-913

* Lund JWG, Kipling C, Le Cren ED (1958) The inverted microscope method of estimating algal numbers and the statistical basis of estimations by counting. Hydrobiologia 11:143-170

*Marañón E (2015) Cell size as a key determinant of phytoplankton metabolism and community structure. Annu Rev Mar Sci 7:241-264

* Marañón E, Cermeño P, López-Sandoval D, RodríguezRamos T and others (2013) Unimodal size scaling of phytoplankton growth and the size dependence of nutrient uptake and use. Ecol Lett 16:371-379

Margalef R (1978) Life forms of phytoplankton as survival alternatives in an unstable environment. Oceanol Acta 1: 493-509

* Menden-Deuer S, Lessard EJ (2000) Carbon to volume relationships for dinoflagellates, diatoms, and other protist plankton. Limnol Oceanogr 45:569-579

Menden-Deuer S, Rowlett J (2014) Many ways to stay in the game: individual variability maintains high biodiversity in planktonic microorganisms. J R Soc Interface 11: 20140031

*Morán XAG, López-Urrutia Á, Calvo-Díaz A, Li WKW (2010) Increasing importance of small phytoplankton in a warmer ocean. Glob Change Biol 16:1137-1144

*Mutshinda CM, Finkel ZV, Irwin AJ (2013) Which environmental factors control phytoplankton populations? A Bayesian variable selection approach. Ecol Modell 269:1-8

Mutshinda CM, Finkel ZV, Widdicombe CE, Irwin AJ (2016) Ecological equivalence of species within phytoplankton functional groups. Funct Ecol 30:1714-1722

Neveux J, Panouse M (1987) Spectrofluorometric determination of chlorophylls and pheophytins. Arch Hydrobiol 109:567-581

*Nogueira E, Pérez FF, Ríos AF (1997) Seasonal patterns and long-term trends in an estuarine upwelling ecosystem (Ría de Vigo, NW Spain). Estuar Coast Shelf Sci 44: 285-300

Nogueira E, Ibanez F, Figueiras FG (2000) Effect of meteorological and hydrographic disturbances on the microplankton community structure in the Ría de Vigo (NW Spain). Mar Ecol Prog Ser 203:23-45

Parsons TR, Maita Y, Lalli CM (1984) A manual of chemical and biological methods for seawater analysis. Pergamon Press, Oxford

Pérez FF, Padín XA, Pazos Y, Gilcoto M and others (2010) Plankton response to weakening of the Iberian coastal upwelling. Glob Change Biol 16:1258-1267

Pinheiro JC, Bates DM (2000) Mixed-effects models in S and S-PLUS. Springer, New York, NY

R Core Team (2017) R: a language and environment for statistical computing. R Foundation for Statistical Computing, Vienna

Reynolds CS (1997) Vegetation processes in the pelagic: a model for ecosystem theory. In: Kinne O (ed) Excellence in ecology, Book 9. Ecology Institute, Oldendorf/Luhe

Kykaczewski RR, Dunne JP (2010) Enhanced nutrient supply to the California Current Ecosystem with global warming and increased stratification in an earth system model. Geophys Res Lett 37:L21606

Santos F, Gómez-Gesteira M, de Castro M, Álvarez I (2012) Variability of coastal and ocean water temperature in the 
upper $700 \mathrm{~m}$ along the Western Iberian Peninsula from 1975 to 2006. PLOS ONE 7:e50666

Sommer U, Charalampous E, Genitsaris S, Moustaka-Gouni M (2017) Benefits, costs and taxonomic distribution of marine phytoplankton body size. J Plankton Res 39: 494-508

Thingstad TF, Ovreas L, Egge JK, Lovdal T, Heldal M (2005) Use of non-limiting substrates to increase size: A generic strategy to simultaneously optimize and minimize predation in pelagic osmotrophs? Ecol Lett 8:675-682

Thomas MK, Kremer CT, Litchman E (2016) Environment and evolutionary history determine the global biogeography of phytoplankton temperature traits. Glob Ecol Biogeogr 25:75-86

UNESCO (1986) Progress in oceanographic tables and

Editorial responsibility: Steven Lohrenz,

New Bedford, Massachusetts, USA standards 1983-1986, work and recommendations of the UNESCO/SCOR/ICES/IAPSO joint panel. UNESCO Tech Pap Mar Sci 50:1-68

Varela M (1992) Upwelling and phytoplankton ecology in Galician (NW Spain) rías and shelf waters. Bol Inst Oceanogr 8:57-74

* Ward BA, Marañón E, Sauterey B, Rault J, Claessen D (2017) The size dependence of phytoplankton growth rates: a trade-off between nutrient uptake and metabolism. Am Nat 189:170-177

Warton DI, Duursma RA, Falster DS, Taskinen S (2012) smatr 3-an R package for estimation and inference about allometric lines. Methods Ecol Evol 3:257-259

Wood SN (2006) Generalized additive models: an introduction with R. CRC Press, Boca Raton, FL

Submitted: June 13, 2017; Accepted: March 2, 2018

Proofs received from author(s): May 14, 2018 